Kok M., H. Massinen, I. Moshnikov, E. Penttilä, S. Tavi \& L. Tuomainen (toim.) 2019. Pidetään kielet elävinä - Keeping languages alive - Piemmö kielet elävinny. AFinLAn vuosikirja 2019. Suomen soveltavan kielitieteen yhdistyksen julkaisuja n:o 77. Jyväskylä. s. 60-76.

Tatsiana Shestunova

University of Helsinki

\title{
Multilingualism in the Finnish preparatory classroom - does it exist?
}

The study was conducted with the aim of exploring Finnish preparatory teachers' attitudes to multilingualism and students' native languages and to examine teachers' rules related to the usage of languages in the classroom. The sample consisted of six teachers employed in state schools in the capital area and in Central Finland. Semi-structured interviews were used as the basic instrument. The data revealed that teachers understand the importance of first language development, and also have a positive attitude towards multilingualism in the classroom on a theoretical level. However, when it comes to practice, teachers place significant limitations on first language use in the classrooms and need more knowledge on how to move from monolingual to multilingual practices. These findings suggest that more attention should be paid to pre- and in-service teacher preparation.

Keywords: second language, first language support, preparatory education 


\section{Introduction}

The need to transform the Finnish education system to meet the needs of the new generation is obvious. Since migration plays a progressively prominent part in Finland (Tarnanen \& Pöyhönen 2015), the education of recently arrived (RA) students has become a key factor in newcomers' wellbeing. Rather than homogeneity and stability, mobility and variety have become the core issues in language study (Blommaert \& Rampton 2011). The perception of multilingualism has turned from treating languages as separate entities, to a focus on practices in which language users deploy all their linguistic features to reach the aim of communication in the best possible way (Jørgensen et al. 2011). The present study contributes to this discussion by concentrating on the role of the first language in the linguistic development of newcomers.

According to the National Agency for Education (2009), the main objective in the Finnish preparatory education is to teach students Finnish or Swedish. In this article, I argue, however, that it is of critical importance to develop and support students' first languages (L1), as strong links exist between L1 development and academic achievements (Cummins 2000; Lopez 2000; Nikièma 2011; Stille \& Cummins 2013). Contextually the study is located in preparatory classrooms, referring to a class where a child is placed for a year upon arrival to Finland in order to learn Finnish. The study focuses on the link between the interaction of students' languages and language arrangement in the classroom in the context of a new school curriculum in Finland. My aim is to contribute to a more comprehensive understanding of how preparatory teachers' views on languages are reflected in the Finnish school and support multilingual development of diverse students. The research questions that I address in this paper are: 1 . What are preparatory education teachers' attitudes to multilingualism? and 2 . What requirements do teachers from preparatory education have towards the languages used in the classroom? The data were collected by interviews and analysed through content analysis.

\section{Towards the norm of multilingual education}

Three basic norms of language behaviour have been outlined in the literature monolingual, bilingual and multilingual (Jørgensen 2008; Hoff et al. 2011; Aronin 2018). In the monolingual norm, one language at a time is seen as an ideal behaviour (Jørgensen 2008). Monolingualism is present everywhere - in education, in language policies, even in discussions about bilingualism, treating a bilingual person as two monolinguals in one, who master both languages at the same level of proficiency (Grosjean 1989). The monolingual approach has long been the norm in language education as shown by state ideologies and language policies (McMillan \& Rivers 
2011). Traditional schools following a monolingual ideology (Cenoz \& Gorter 2014) expect a teacher-student interaction in the authorised language only.

In response to the monolingual bias, an array of concepts has emerged to signify the discursive character of language systems - continua of biliteracy (Hornberger 2003) based on a view of multilingualism as a resource, metrolingualism (Otsuji \& Pennycook 2010), polylanguaging (Jørgensen et al. 2011), codemeshing (Canagarajah 2011), and translanguaging (García \& Wei 2014). These concepts have encapsulated the shift from monolingual to multilingual norm in language education. According to Aronin (2018), multilingualism describes the use of three or more languages. In his definition of multilingualism, Grosjean (1982) refers to the concept at a societal level as the co-existence of two or more languages in one society. Other researchers address the degree of proficiency that individuals should possess. For example, while Bloomfield (1933: 56) defines multilingualism as "a native-like control of two or more languages", MacNamara (1967: 59) states that a bilingual individual "possess at least one of the language skills even to a minimal degree in their second language".

There is a large volume of studies describing the acquisition of language proficiency (Thompson 1952; Singer 1956; Peal \& Lambert 1962; MacNamara 1966; Cutler et al. 1989). They reflect that traditionally transfers from one language to another have been regarded as negative (Cenoz \& Gorter 2014). Students'languages have been seen as an obstacle to mastering the mainstream language and to academic progress (Cummins 1989). According to Cenoz and Gorter (2014), this ideology is still spread in the educational setting and teachers still hold the opinion that they have to isolate the target language from the other languages the students speak.

However, Cummins' interdependence hypothesis (1978) states that first language development influences the learner's L2. Students with high academic and conceptual skills in L1 will attain high academic skills in L2 (Cummins 2000). A number of studies support the hypothesis. Thus, Dweik and Abu Al Hommos (2007) examined writing skills of 20 bilingual students studying English in Jordan. The researchers concluded that Arabic writing skills can be transferred to English regardless of the difference between these languages.

Other studies claim that L1 supports students' academic achievements. Ito (2004) made a parallel between Japanese EFL students' L1 and L2 composition scores, and their L2 knowledge. Goldenberg, Rueda and August (2006) pointed out that students understand better when they read texts in a language they know better. Bruen and Kelly (2017) argue that the learning process can be enhanced using a shared L1 in the L2 classroom. In their opinion, L1 reduces cognitive overload and creates a relaxed atmosphere promoting students' engagement and diminishing their feeling of being overwhelmed. In the same way, García (2009) recognises the importance of L1 and argues that students apply the skills learnt through the first 
language in the development of their bilingualism. Languages work together and complement each other. Hence, the use of L1 facilitates understanding of school disciplines and promotes academic development and achievements.

Thus, considering all the views mentioned above, it is clear that the era of multilingualism sets a value upon the linguistic potential of an individual, lays down new challenges to the educational system, and emphasises the importance of the languages students possess.

\section{Methodology and data}

\subsection{Research design}

The aim of this study is to explore Finnish preparatory teachers' attitudes to multilingualism in the classroom and to examine teachers' rules related to the usage of languages in classrooms. A qualitative approach was considered the most appropriate to address the research questions, as it aims at understanding people's lives, creating contextual visions of their experiences and their interpretations (Schultze \& Avital 2011). Semi-structured interviews are used widely in qualitative research (Holloway \& Wheeler 2010). Face-to-face interviews are relevant when a researcher has to deal with sensitive topics (Dempsey et al. 2016), as they allow participants to feel safe when discussing their life experiences with a stranger (Knox \& Burkard 2009). All interviewees gave their explicit consent to being interviewed and audio-recorded. Throughout the research, the respondents were assigned special codes and their names were changed. All information leading to a disclosure of their identities or school names was removed.

Semi-structured interviews involved six preparatory education teachers (all females) covering urban areas from the capital region and Central Finland. I selected participants randomly and contacted them by e-mail. The experiences of preparatory teachers were examined during one school year. The semi-structured interviews, conducted in English, fluctuated between a formal discussion of the questions prepared and sent to teachers in advance and an informal dialogue around the raised topics. The interviews aimed at: (1) positioning the teacher's background; (2) identifying their attitudes to the students' languages; (3) examining language arrangements in the classroom with regard to students' L1. The interviewer could vary the questions and ask for clarification or additional information.

The interviews took between 30 and 60 minutes. They were recorded and transcribed verbatim to maximise the accuracy of the data. This enhanced the validity of data analysis (Bennett et al. 2001). Further, I coded the data as per the procedure described by Kuckartz (2014). The themes were generated inductively 
from the produced data. A thematic matrix was constructed to represent individual case summaries and thematic summaries. The analysis of the study concentrated on what the respondents articulated about their background, attitudes and practices towards the languages in their classrooms. In addition, Macaro's (2001) positions on second language teaching were used to analyse teachers' attitudes towards language choices in the classroom.

\subsection{Data and participants}

The total response rate of the interviews was extremely low - only 14 per cent of all the people invited agreed to participate in the research. However, the low rate was expected, since the interviews were announced to be carried out in English. Such outcomes may also stem from a lack of interest among teachers in sharing their attitudes and experiences. In other words, the topic of the interview may not have been the main concern that teachers felt a need or desire to respond to. Table 1 below provides information about teachers' background and their education.

TABLE 1. Profile of participants.

\begin{tabular}{|l|l|l|l|l|l|l|}
\hline & Onna & Ilona & Emmi & Noora & Hanna & Leila \\
\hline $\begin{array}{l}\text { Immigrant } \\
\text { background }\end{array}$ & + & - & + & - & + & - \\
\hline Work abroad & + & + & - & - & - & + \\
\hline Study abroad & + & + & - & - & - & - \\
\hline $\begin{array}{l}\text { Previous work in } \\
\text { multilingual settings }\end{array}$ & + & + & - & + & + & + \\
\hline $\begin{array}{l}\text { Class teacher } \\
\text { education }\end{array}$ & + & + & + & + & + & + \\
\hline $\begin{array}{l}\text { Special education } \\
\text { specialisation }\end{array}$ & - & - & + & - & - & - \\
\hline Teaching Finnish as L1 & - & - & - & - & - & + \\
\hline Experience, years & 8 & 8 & 7 & 6 & 4 & 4 \\
\hline
\end{tabular}

All informants had experience of either living or working in multilingual settings. Three of the six teachers had an immigrant background. All the teachers graduated from Finnish universities with a Master's degree qualified as a class teacher. However, there is a significant difference in their initial university education and further training. For example, one teacher had completed environmental studies, the other graduated from the University of Applied Sciences and studied marketing there. None of the participants was qualified as a Finnish as a second language teacher. However, one of the respondents had a qualification as a teacher of Finnish as a mother tongue. 
As they put it, all the teachers went into their profession "by accident"; none of them chose to teach in preparatory classes intentionally. Moreover, two teachers did not understand what this job meant in practice.

\section{$4 \quad$ Results}

The results in this section (see Figure 1) are organised according to the research questions presented above and the themes emerged in the course of analysis in the following order: 1) teachers' attitudes to multilingualism; 2) language arrangement in the classroom; 3) teachers' expertise; and 4) norms of language behaviour in the classroom.

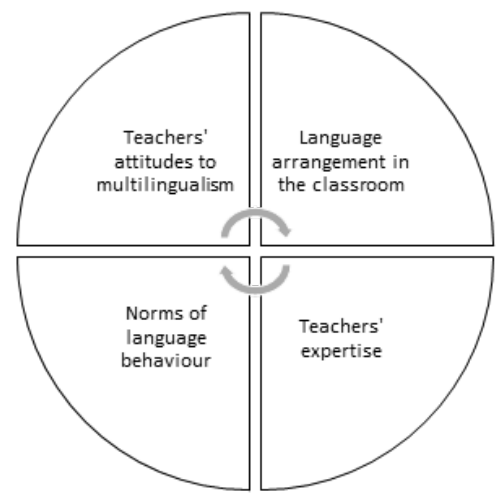

FIGURE 1. A résumé of the emerged themes.

\subsection{Teachers' attitudes to multilingualism}

The first question in the study was: What are preparatory education teachers' attitudes to multilingualism? The analysis of the interview data suggested that participants' attitudes to multilingualism centre around two paradigms: general attitudes to multilingualism and attitudes to the students' first languages.

The first paradigm was analysed based on the information provided in response to the question whether multilingualism should be encouraged in the classroom or whether the students should speak only Finnish. The results demonstrate that all the respondents hold a positive opinion about multilingualism. Talking about this issue an interviewee said (here and later interviewees' comments are presented in italics with quotation marks), "Absolutely, it should be encouraged to have multilingual children". Commenting on the issue under consideration, the other interviewee stated: "Ah, promoted... For sure. Everything. I mean, yes, surely". A surprising aspect of the data was that the respondents justified their positive 
views by referring to different factors. In one case, a teacher explained the necessity of promoting multilingualism by the new Finnish curriculum: "It is a new teaching opetussuunnitelma ... the national teaching plan is pushing learning on the multilingual side." At the same time, other interviewees alluded to the notion of language variety in the world: "We should open our minds to the idea that there are many languages in the world. None of these languages is better than the other, or right or wrong." We can see that the teacher acknowledged the linguistic diversity of the world. She believed that all languages were a valuable instrument of communication and that the importance of each language should be recognised. This view was echoed by other informants who stated that "positive thinking about different languages is important" and "I love Finnish. It's important for me, but it's just one language in this world."

If we now turn to the respondents' attitudes to the students' languages, the results demonstrate that in general, all the teachers had positive attitudes to their students' L1. In most cases, they perceived the native language as a resource for both a student and a teacher. When addressing the issues of the first language, the respondents used such descriptors, as skills, power, language of your heart and soul, the most important language, in a way that demonstrated their respect and loyalty.

All the respondents taught their students to value their language. Their excerpts contained arguments that encouraged children to consider the significance of their mother tongues, seeing them as an integral part of human life: "The home language is important because it is a part of the student's life history"; "The native language makes people what they are. You can't be a part of anything. You can be your whole self and you can speak any language you want"; "The mother tongue is really important, because it's your reality, your friend, your history."

In addition, teachers held a common opinion that the first language served as a basis for constructing further knowledge and demonstrated their awareness that knowledge was transferred from one language to another. Their position was shown by such statements as "I know the importance of the mother tongue in order to learn certain time concepts and languages"; "It's really important that you know those things in your mother tongue." The other respondent displayed her knowledge that it was important for a child to understand the information in L1, for example, abstract concepts: "Because if you just speak Finnish, the students might learn for a long time without really understanding what the word is standing for. They will not connect things with each other." The interviewees clearly believed that students should use their home language, as in the following excerpts: "Languages are resource and students should use all the skills they have. It's not wise to prohibit using any skills"; "There are so many studies and we know that multilingual children and their brains function in a different way and it's very helpful for them in many ways". It is interesting that some teachers used the student's language in assisting learning: "Let's say, I have two students who speak the same language. If I know that one of them has understood, then I say 'Ok. Explain that to your friend, go through this together.' 
To summarise, these results demonstrated that preparatory education teachers have a positive opinion about multilingualism. They acknowledge the linguistic diversity of the students and understand the value of the native language, seeing it as a resource, power and support.

\subsection{Language arrangement in the classrooms}

The second question addressed in the research was: What requirements do teachers from preparatory education have towards the languages used in the classroom?

Overall, teachers stated that L1 in the classroom was permitted, however, there were considerable limitations. In all cases, native languages were allowed during breaks or during free time. For two teachers, the language use depended on the students' individual skills. Nevertheless, most of the respondents believed that during the lessons, students should only speak Finnish. Noora, for example, justified her opinion that Finnish should be the only language in the classroom thus: "When we are in the classroom, I say, that, now remember to use Finnish language, because that's the only language that we share." On the other hand, despite her view mentioned above, she was one of the two teachers who allowed the use of L1 during lessons of the Finnish language, commenting that the native language facilitated and supported L2. In the same way, Emmi allowed pupils to speak their native language all the time if their Finnish developed well. However, according to her, if students did not try speaking Finnish at all, they should be prevented from speaking $L 1$ in the classroom.

Ilona commented that in the lessons and in the classroom, she expected her students to speak only Finnish. L1 was allowed during breaks out of the classroom. In her opinion, if any of the minority languages prevailed, it could cause problems in the classroom: "But also if there is a dominant language it's a problem in the classroom. So we have to say the students every day to stop talking in some language in order to speak Finnish."

Hanna said that teachers mainly used Finnish in preparatory classrooms so that the children would learn Finnish. She allowed the use of Google Translate or speaking the native language with friends to the students who had just arrived. However, those who were in the class for more than 6 months, were required to speak Finnish only during the classes.

Leila considered that when learning and practising Finnish, only Finnish should be used. During other lessons and recesses other languages could be used. As mentioned above, Onna often used her students' native languages when explanations were needed. She did not see any point in explaining the Finnish grammar if students did not understand basic concepts like parts of speech in their native language. On the other hand, in her opinion, a teacher should be watchful and make sure that the students discussed in L1 only things that related to a specific task. 
It was interesting to pay attention to the verbs the teachers used when discussing the language arrangements in the classroom. The linguistic repertoire used when requiring students to speak the target language included: "I say", "I demand", "I have to say", "you should stick to Finnish". However, when they articulate that students are allowed to use their L1 during breaks, in most cases the interviewees use "encourage", "you can". These examples allow me to conclude that speaking Finnish in the classroom is placed on the level of demand, whereas speaking the native language is a soft permission. The results indicate that even though teachers understand the value of the first language at a theoretical level, they have limitations in L1 use at a practical level.

\subsection{Teachers' expertise}

The theme of teachers' expertise emerged from discussion of the issues of multilingualism. All the respondents consider themselves as possessing an adequate expertise to meet the needs of multilingual learners. They give a definite "yes" to the question whether they feel that they have this expertise. However, they justify it by different factors (see Figure 2).

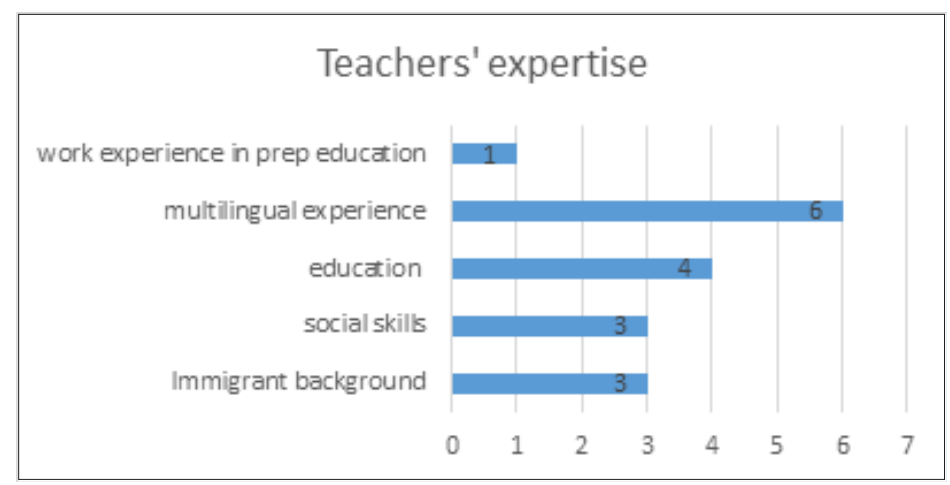

FIGURE 2. Factors of teachers' expertise.

The most interesting finding is that only one teacher referred to the experience of being a preparatory teacher as the key factor of her expertise. The most mentioned factor was a multilingual experience. This category includes living or studying abroad, as well as work with immigrants out of the school, for example, work in refugee camps. Special social skills and immigrant background were mentioned by 50 per cent of the respondents. Three teachers referred to their immigrant background as to the fact facilitating communication with students. 
Most of the respondents mentioned several factors when referring to the issue of expertise. For example, llona grounded a positive opinion about her high expertise on the fact that she worked with immigrants and has had a 7-year experience in preparatory education. Emmi felt that she had good expertise due to her immigrant background. She also related her expertise to multicultural studies and her special needs specialisation. An interesting observation to emerge from the data is that all the respondents referred to special needs education or teaching Finnish as a second language as a wished-for component of preparatory teacher education. They place students from preparatory education on the same level with students who have special needs, although acknowledging that these needs are special only in terms of the language.

Noora believed that teachers should neither concentrate on students' differences nor strive to look for those differences. She justified her high expertise by a specific attitude to children and work "I think that it's not that what I have studied. It's how I do my work and what are my attitudes towards any... any child or...." Hanna grounded her positive opinion on her education in behavioural studies. In addition, she was empathetic and sympathetic to children with tragic histories.

\subsection{Language norms in the classroom}

In "Analyzing student teachers' codeswitching in foreign language classrooms", Macaro (2001) has developed perspectives on multiple language use including virtual, maximal and optimal positions, thus ranging from monolingual ideology to multilingualism. From the interviews, it is clearly seen that the virtual or monolingual position based on the idea that the second language can be learned only and exclusively through this language, still exists in the classroom. This position was supported by such statements as "we have to say the students every day to stop talking in some language in order to speak Finnish", "in the class we speak Finnish", "now remember to use Finnish language", and "if you want learn Finnish, you have to use it". The respondents justified their monolingual position by such factors as the students having to learn Finnish, Finnish being the only shared language in the classroom, some students not trying to speak Finnish at all, etc.

The maximal position prioritises the use of $L 2$ in the classroom; however, it does not stress the harmfulness of L1 use. This viewpoint is observed in the following statement: "in preparation class and with the immigrants we speak... we use mainly Finnish". This statement could be referred to the first position, but the teacher uses the word "mainly", showing that she strives to use the second language in the classroom, but for some reason, this provision is unreachable, and, in some cases, other languages are spoken. 
Under Macaro's (2001) last position, shifting to multilingualism, the value of the first language is recognised and teachers use it to enhance learning. The evidence for this position is found in such statements as "I do always tell the students how important their mother tongue is", and "all of my students go to their home language in studies".

The most surprising aspect of the data is that each teacher at the same time keeps all three positions. We can observe it, for instance, following one teacher's statements: "in the class we speak Finnish", "if there is a dominant language, it's a problem in the classroom", and "I know the importance of the mother tongue in order to learn certain time concepts". The three language teaching positions are clearly traced in these arguments, representing their coexistence at the same time in the Finnish preparatory classroom.

\section{Discussion}

The set of questions aimed at understanding teachers' attitudes to multilingualism and language arrangement in the classroom. The most obvious finding emerging from the analysis is that all the teachers held a positive attitude towards multilingualism. They understood the importance of L1 and encouraged students to be proud of their own language. The respondents see the students' language as a resource and find support in it for the development of Finnish as L2. These results confirm Ta's (2015) findings, which showed that the use of L1 acts as an effective scaffolded help for students in task completion and management. In addition, recognising the value of the students' languages, a teacher creates a safe space, promotes well-being in the classroom and reinforces the learners' self-esteem (Mary \& Young 2017).

However, the use of the first language in the classroom is restricted by teachers' practices. The analysis clearly showed that while some teachers allow L1 to be spoken during lessons, the others believed that the main idea of education in preparatory class was to learn Finnish and demanded that only Finnish should be spoken. They justified this requirement by the fact that Finnish was the only common language in the classroom or that L1 could be used for bullying. They assumed that L1 might prevent students from learning Finnish. However, this monolingual vision can lead to the academic failure of diverse learners (Garcia \& Hesson 2015: 221), as L2 speakers are expected to achieve the same language proficiency as L1 speakers (Cook 2001).

The findings support Lee and Oxelson's (2006) research related to English language teaching. According to them, teachers without special training believed that more time and exposure to English led to faster and better English language acquisition. In this respect, it is important to mention that at present national requirements for the Finnish preparatory teacher qualification have not yet been 
defined, though new recommendations were offered by the Kuski project (Tainio et al. 2019). Local educational departments specify their own requirements, usually demanding a qualification as either a class teacher or a special needs teacher. Discrepancies in teachers' positive views on multilingualism and their monolingual practices imply that, even though Finnish teachers understand the importance of L1 in learning, they are short of appropriate knowledge on how to implement the theory in practice or how to make the best out of students' linguistic potential.

Teacher education also needs to be taken into consideration. Although all the teachers considered themselves experts in the field, the study showed that the respondents felt that their education was lacking in functional knowledge. They referred to special needs education as an important constituent of preparatory teacher education. The parallel between preparatory and special needs education is obvious. In both cases students demand tailor-made programmes that consider their individual differences. However, in preparatory education, individual differences refer more to cultural aspects, age, and background of a student. Both preparatory and special needs education require specific methods from teachers and in both cases the learner's progress is evaluated individually. On the other hand, preparatory education teachers should be able to distinguish real learning difficulties and difficulties caused by the under-development of the Finnish language skills. The problem is complicated by the absence of appropriate methodologies aimed at differentiating between learning and linguistic difficulties.

In addition to special needs knowledge, the interviewees refer to the education of teaching Finnish as the second language. A possible explanation for this might be that preparatory teachers do not act only as language teachers. Their secondary role is as integrators, as respondents who have a more complicated task - within a year they have to teach the language up to a level in which students are able to continue their education in the mainstream class. It is important to note that none of the interviewees was trained as a teacher of Finnish as a second language. Only one respondent was qualified as a teacher of Finnish as L1.

Prior studies have noted the importance of culturally responsive teaching (Gay 2002; Stooksberry et al. 2009). Teachers in preparatory classrooms have to deal with a population of diverse origins, religions, backgrounds. The respondents in the study had diverse backgrounds themselves, including immigrant origins, work in refugee camps, and studies or work abroad. It can therefore be assumed that their opportunities to cooperate with people from diverse backgrounds were maximal, and they demonstrated that their experiences helped them to communicate with RA students and facilitated their understanding of students' needs.

Currently, all three norms of language behaviour co-exist in Finland. Officially being a bilingual country, Finland has been "marked by a strongly monolingual and monocultural self-imagination" (Blommaert et al. 2012: 13), and Finnish schools remain monolingual, keeping Finnish and Swedish as separate languages of 
instruction. In practice, education policies are often aiming to submerse students into the majority language. Within this perspective, the home language of these students has no place in the classroom and is not included in the curriculum. At the same time a shift to multilingual vision is taking place. While the European Commission has declared that all citizens in Europe should acquire knowledge and skills in two foreign languages in addition to their mother tongue (Commission of the European Communities 2003), a new Finnish school curriculum (National Agency for Education 2015) promotes multilingualism in all its forms, clearly stating that students' languages should be cherished and used as a resource. This phenomenon is distinctly expressed in the metropolitan area; however, the current research claims that it is neither so visible in other parts of the country, nor is it yet seen in teacher education (Tainio et al. 2019; Ahlholm \& Tainio 2019). The supporters of multilingual education policies argue that students benefit from education in their own language - in addition to or in combination with $L 2$.

\section{Conclusion}

The research findings point that all three norms of language behaviour (monolingualism - bilingualism - multilingualism) are present today in the Finnish preparatory classroom. Until teachers believe in the benefits of greater exposure to the target language and unless they start using their students' languages as a resourse, it is unlikely that the need to promote students' L1 will enter into their interest area.

Besides, preparatory teachers need more multidisciplinary learning (Tainio et al. 2019). A reasonable approach to tackle this issue could be to offer more training in multilingual and cultural competence specifically aimed at promoting and supporting students' L1. Moreover, teachers should acquire more knowledge about the specificities of the development of multilingual students and linguistically responsive teaching. The recommendations about special qualifications of preparatory teachers are also contained in the Kuski-hanke report (Tainio et al. 2019). The results of this study can be used to suggest that future teachers should be exposed to culturally and linguistically diverse environments and should have more opportunities for practical experience with multilingual learners.

Educational philosophy implies that a modern educational system should provide opportunities for the development of all the languages students possess, whereas schools should create a safe space where students are empowered to use all their linguistic resources. The National Agency for Education (2015) has declared cultural competence to be one of the components of transversal competences and has urged teachers to use students' linguistic repertoires as a valuable resource for learning. 
Even in the light of the new Finnish curriculum focused on the students' L1, a major change in attitudes and beliefs is needed together with more research illuminating how the change of attitudes translates into teaching practices.

\section{References}

Ahlholm, M. \& L. Tainio 2019. Kielitilastoista toimintaan: riittääkö pieni jousto vai tarvitaanko rakenteellisia uudistuksia? Kieli, koulutus ja yhteiskunta, 10 (3). https:// www.kieliverkosto.fi/fi/journals/kieli-koulutus-ja-yhteiskunta-huhtikuu-2019/ kielitilastoista-toimintaan-riittaako-pieni-jousto-vai-tarvitaanko-rakenteellisiauudistuksia.

Aronin, L. 2018. Lecture 1: What is multilingualism? In D. Singleton and L. Aronin (eds) Twelve lectures on multilingualism. Bristol: Multilingual Matters, 3-34.

Bennett, S. J., S. M. Perkins, K. A. Lane, M. A. Forthofer, D. C. Brater, D. C. \& M. D. Murray 2001. Reliability and validity of the compliance belief scales among patients with heart failure. Heart \& Lung: The Journal of Acute and Critical Care, 30 (3), 177-185. https://doi. org/10.1067/mhl.2001.114193

Blommaert, J., S. Leppänen, P. Pahta \& T. Räisänen (eds.) 2012. Dangerous multilingualism: Northern perspectives on order, purity and normality. New York: Palgrave Macmillan.

Blommaert, J. \& B. Rampton 2011. Language and superdiversity. Diversities, 13 (2), 1-21. www.unesco.org/shs/diversities/vol13/issue2/art1.

Bloomfield, L. (1933). Language. New York: Henry Holt.

Bruen, J. \& N. Kelly 2017. Using a shared L1 to reduce cognitive overload and anxiety levels in the L2 classroom. The Language Learning Journal, 45 (3), 368-381. https://doi.org/10.1 080/09571736.2014.908405.

Canagarajah, S. 2011. Codemeshing in academic writing: identifying teachable strategies of translanguaging. The Modern Language Journal, 95 (3), 401-417. https://doi. org/10.1111/j.1540-4781.2011.01207.x.

Cenoz, J. \& D. Gorter 2014. Focus on multilingualism as an approach in educational contexts. In A. Blackledge \& A. Creese (eds) Heteroglossia as practice and pedagogy. Dordrecht: Springer, 239-254.

Commission of the European Communities 2003. Promoting Language Learning and Linguistic Diversity: An Action Plan 2004-2006. https://eur-lex.europa.eu/LexUriServ/LexUriServ. do?uri=COM:2003:0449:FIN:EN:PDF

Cook, V. 2001. Using the first language in the classroom. Canadian Modern Language Review, 57 (3), 402-423. https://doi.org/10.3138/cmlr.57.3.402

Cummins, J. 1978. Educational implications of mother-tongue maintenance in minority language groups. The Canadian Modern Language Review, 35, 395-416. https://doi. org/10.3138/cmlr.34.3.395.

Cummins, J. 1989. Language and literacy acquisition in bilingual contexts. Journal of Multilingual \& Multicultural Development, 10 (1), 17-31. https://doi.org/10.1080/01434 632.1989.9994360.

Cummins, J. 2000. Language, power and pedagogy: bilingual children in the crossfire. Clevedon: Multilingual Matters.

Cutler, A., Mehler, J., Norris D. \& J. Segui 1989. Limits on Bilingualism. Nature 340 (6230), 229230. http://dx.doi.org/10.1038/340229a0

Dempsey, L., M. Dowling, P. Larkin \& K. Murphy 2016. Sensitive interviewing in qualitative research. Research in Nursing \& Health, 39 (6), 480-490. https://doi.org/10.1002/ nur.21743 
Dweik, B. S. \& M. D. Abu Al Hommos 2007. The effect of Arabic proficiency on the English writing of bilingual-Jordanian students. https://files.eric.ed.gov/fulltext/ED497505.pdf [accessed 5 January 2019].

Garcia, O. 2009. Education, multilingualism and translanguaging in the 21 st century. In T. Skutnabb-Kangas, R. Phillipson, A. K. Mohanty \& M. Panda, M. (eds) Social justice through multilingual education. Bristol: Multilingual Matters, 140-158.

García, O. \& S. Hesson 2015. Translanguaging frameworks for teachers: macro and micro perspectives. In A. Yiacoumetti (ed.) Multilingualism and language in education: current sociolinguistic and pedagogical perspectives from commonwealth countries. Cambridge: Cambridge University Press, 221-242.

García, O. \& L. Wei 2014. Translanguaging: language, bilingualism and education. Houndmills: Palgrave Macmillan.

Gay, G. 2002. Preparing for culturally responsive teaching. Journal of Teacher Education, 53 (2), 106-116. https://doi.org/10.1177\%2F0022487102053002003

Goldenberg, C., R. S. Rueda \& D. August. 2006. Synthesis: sociocultural contexts and literacy development. In D. August \& T. Shanahan (eds), Developing literacy in secondlanguage learners: report of the national literacy panel on language-minority children and youth. Mahwah, NJ: Lawrence Erlbaum Associates, 249-267.

Grosjean, F. 1982. Life with two languages: an introduction to bilingualism. Cambridge, MA: Harvard University Press.

Grosjean, F. 1989. Neurolinguists, beware! The bilingual is not two monolinguals in one person. Brain and language, 36 (1), 3-15. https://doi.org/10.1016/0093934X(89)90048-5

Hoff, E., Core, C., Place, S., Rumiche, R., Señor, M. \& M. Parra 2011. Dual language exposure and early bilingual development. Journal of Child Language, 39 (1), 1-27. https://doi. org/10.1017/S0305000910000759

Holloway, I. \& S. Wheeler 2010. Qualitative research in nursing \& healthcare. 3rd edition. Oxford: Wiley-Blackwell.

Hornberger, N. H. (ed.) 2003. Continua of biliteracy: an ecological framework for educational policy, research, and practice in multilingual settings. Clevedon: Multilingual Matters.

Ito, F. 2004. The Interrelationship among first language writing skills, second language writing skills, and second language proficiency of EFL university students. JACET Bulletin, 39, 43-5. http://www.eric.ed.gov [accessed 19. September 2019].

Jørgensen, J. N. 2008. Polylingual languaging around and among children and adolescents. International Journal of Multilingualism, 5(3), 161-176. https://doi. org/10.1080/14790710802387562.

Jørgensen, J. N., M. S. Karrebæk, L. M. Madsen \& J. S. Møller 2011. Polylanguaging in superdiversity. Diversities, 13 (2), 23-38. https://unesdoc.unesco.org/ark:/48223/ pf0000214772.nameddest $=214781$.

Knox, S. \& A. W. Burkard 2009. Qualitative research interviews. Psychotherapy Research, 19, 566-575. https://doi.org/10.1080/10503300802702105

Kuckartz, U. 2014. Qualitative text analysis: a guide to methods, practice \& using software. London: SAGE Publications.

Lee, J. S. \& E. Oxelson 2006. “It's not my job": K-12 teacher attitudes toward students' heritage language maintenance. Bilingual Research Journal, 30 (2), 453-477. https://doi.org/10. 1080/15235882.2006.10162885.

Lopez, L. E. 2000. The development and use of first and second languages in bilingual education: an introduction for educational planners in multicultural and multilingual contexts. https://www.researchgate.net/profile/Luis_Lopez172/ publication/237114123_The_development_and_use_of_first_and_second_ 
languages_in_bilingual_education_an_introduction_for_educational_planners_ in_multicultural_and_multilingual_contexts/links/590225ebaca2725bd7222539/ The-development-and-use-of-first-and-second-languages-in-bilingual-educationan-introduction-for-educational-planners-in-multicultural-and-multilingual-contexts. pdf_[accessed January 17, 2019].

Macaro, E. 2001. Analyzing student teachers' codeswitching in foreign language classrooms: theories and decision making. The Modern Language Journal, 85 (4), 531-548.

MacNamara, J. 1966. Bilingualism and primary education: a study of the Irish experience. Edinburgh: Edinburgh University Press.

MacNamara, J. 1967. The bilingual's linguistic performance - a psychological overview. Journal of Social Issues, 23 (2), 58-77. https://doi. org/10.1111/j.1540-4560.1967.tb00576.x.

MacNamara, J. 1969. How can one measure the extent of a person's bilingual proficiency? In L. Kelly (ed.), Description and measurement of bilingualism: an international seminar, University of Moncton, June 6-14. Toronto: University of Toronto Press, 80-97.

Mary, L. \& A. S. Young 2017. Engaging with emergent bilinguals and their families in the pre-primary classroom to foster well-being, learning and inclusion. Language and Intercultural Communication, 17 (4), 455-473. https://doi.org/10.1080/14708477.201 7.1368147.

McMillan, B. A. \& D. J. Rivers 2011. The practice of policy: Teacher attitudes toward “English only." System, 39 (2), 251-263. https://doi.org/10.1016/j.system.2011.04.011.

National Agency for Education 2009. National Core Curriculum for Basic Education. https:// www.oph.fi/download/138886_national_core_curriculum_for_instruction_ preparing_for_basic_education_2009.pdf [accessed 5 January 5, 2019].

National Agency for Education 2015. Lukion opetussuunnitelman perusteet. [Finnish Core Curriculum for Upper Secondary Education]. http://www.oph.fi/download/172124 lukion_opetussuunnitelman_perusteet_2015.pdf [accessed 3 January, 2018].

Nikièma, N. 2011. A first-language-first multilingual model to meet the quality imperative in formal basic education in three "francophone" West African countries. International Review of Education / Internationale Zeitschrift Für Erziehungswissenschaft, 57 (5/6), 599-616. https://doi.org/10.1007/s11159-011-9253-5.

Otsuji, E. \& A. Pennycook 2010. Metrolingualism: fixity, fluidity and language in flux. International Journal of Multilingualism, 7 (3), 240-254. https://doi. org/10.1080/14790710903414331.

Peal, E. \& W. E. Lambert 1962. The relation of bilingualism to intelligence. Psychological monographs: general and applied, 76 (27), 1. https://psycnet.apa.org/doi/10.1037/ h0093840.

Schultze, U. \& M. Avital 2011. Designing interviews to generate rich data for information systems research. Information and Organisation, 21(1), 1-16. https://doi.org/10.1016/j. infoandorg.2010.11.001.

Singer, H. 1956. Bilingualism and Elementary Education. The Modern Language Journal, 40 (8), 444-458. 10.2307/319746. https://www.jstor.org/stable/319746

Stille, S. \& J. Cummins 2013. Foundation for learning: engaging plurilingual students' linguistic repertoires in the elementary classroom. TESOL Quarterly, 47 (3), 630-638, https://doi.org/10.1002/tesq.116.

Stooksberry, L. M., D. L. Schussler \& L. A. Bercaw 2009. Conceptualizing dispositions: intellectual, cultural, and moral domains of teaching. Teachers and Teaching: Theory and Practice, 15 (6), 719-736. https://doi.org/10.1080/13540600903357041. 
Ta, B. T. 2015. The role of the first language in meaning-focused and form-focused second language learning. Journal of Second Language Teaching \& Research, 4 (1), 24-37. http://pops.uclan.ac.uk/index.php/jsltr/article/view/311.

Tainio, L., A. Kallioniemi, R. Hotulainen, M. Ahlholm, R. Ahtiainen, M. Asikainen \& N. Virkkala 2019. Koulujen monet kielet ja uskonnot. Selvitys vähemmistöäidinkielten ja -uskontojen sekä suomi ja ruotsi toisena kielenä-opetuksen tilanteesta eri koulutusasteilla [Multilingualism and religions in schools. Report on the state of minority languages, religion, Finnish and Swedish as a second language at different levels of education] http://julkaisut.valtioneuvosto.fi/bitstream/10024/161302/1/11-2019-KUSKI.pdf [accessed 30 January, 2019].

Tarnanen, M. \& S. Pöyhönen 2015. Integration policies and adult second language learning in Finland. In J. Simpson \& A. Whiteside (eds) 2015. Adult language education and migration: challenging agendas in policy and practice. Abingdon: Routledge, 125-136.

Thompson G. 1952. Child Psychology. Boston: Houghton Mifflin. 